\title{
複眼ビジュアルサーボによる水中ロボットの実海域嵌合実験
}

\author{
米森 健太 ${ }^{* 1}$ ，矢納 陽 ${ }^{* 2}$, Myo MYINT*1, Khin Nwe LWIN*1, 見浪 護*3
}

\section{Docking experiment of underwater vehicle by dual-eye visual servoing in sea}

\author{
Kenta YONEMORI ${ }^{* 1}$, Akira YANOU*2, Myo MYINT ${ }^{* 1}$, Khin Nwe LWIN*1 \\ and Mamoru MINAMI ${ }^{* 3}$ \\ ${ }^{* 1,{ }_{3} 3}$ Graduate School of Natural Science and Technology, Okayama university \\ 3-1-1 Tsushimanaka, Kitaku, Okayama 700-8530, Japan \\ ${ }^{*}$ Kawasaki College of Allied Health Professions, Department of Radiological Technology \\ 316 Matsushima Kurashiki-shi, Okayama 701-0194, Japan
}

Received: 7 September 2016; Revised: 12 December 2016; Accepted: 6 March 2017

\begin{abstract}
A variety of robots has been studied and developed for undersea exploration. One of the applications for undersea exploration is mining of undersea resources such as methane hydrate and rare metal by Autonomous Underwater Vehicle (AUV). To extend active duration time of the robot in the sea, a system through which the AUVs recharge autonomously batteries is a key technology. The authors have confirmed in a pool environment the dual-eye visual servoing system made a pole attached to the vehicle dock into a pipe that simulates recharging station, but the abilities have not been verified in real sea environment. The purpose of this paper is to scrutinize the capability that the visual servoing system can conduct docking operation in real sea, which has disadvantage like impurity deducting visible distance comparing a condition in a pool filled with tap water and disturbances made by waves and currents. The docking has been conducted five times and four docking trials have been successfully completed, and all four succeeded docking data have been presented in detail with behavior analyses of the robot in the sea.
\end{abstract}

Key words : ROV, Visual servoing, Genetic algorithm, AUV

\section{1. 緒言}

近年，海底探査等のために様々な水中ロボットが研究・開発されている. 海底マッピング，水中生物の生態調査， 地下資源の採掘など研究の目的は多様である。これらの実現には水中での長時間活動が必要とされるが，長時間 にわたり水中ロボットを操縦者が手動で操作することは多大な労力を要すだけでなく，集中力も求められる．この 操縦者の負担を軽減するためには，ビジュアルサーボを用いた水中ロボットの自動制御によって位置・姿勢の安 定化制御を行い，状況に応じて操縦者が制御の目標值を与えるという半自動制御の実現が望ましい.

現在，ロボットへの電力供給方法には有線とバッテリーの二つの方法が主流であるが，いくつか問題点がある. 例えばROV（Remotely Operated Vehicle，有線を用いた遠隔操縦型の水中ロボット）の場合，ケーブルが海底の岩 との接触等で損傷しやすく，また深海に潜るためにはケーブル自体が数千 $\mathrm{m}$ の長さになり，その張力の影響によ り水中ロボットの遠隔操作は難しい作業となる. バッテリーによる電力供給の場合, 活動可能時間が充電されたエ

No.16-00410 [DOI:10.1299/transjsme.16-00410], J-STAGE Advance Publication date: 24 March, 2017

${ }^{* 1}$ 岡山大学大学院自然科学研究科（下700-8530 岡山県岡山市北区津島中 3-1-1）

*2 正員，川崎医療短期大学放射線技術科（干701-0194 岡山県倉敷市松島 316）

*3 正員, 岡山大学大学院自然科学研究科

E-mail of corresponding author: pceo8sjx@s.okayama-u.ac.jp 
ネルギー量に依存するという問題があり, 充電のたびに船舶と作業場所を往復しなけれげならないため効率的な 運用ができない。これらの問題を解決し水中での活動時間を延ばすために, 水中に給電設備を設置しロボットが自 動で充電を行うシステムの研究が行われている，著者らは，ステレオカメラにより取得した視覚情報を用いた 3 次元位置・姿勢認識によって, 水中ロボットの制御を実現している（矢納他，2014, 2016）。提案した実時間遺伝 的認識手法は, 三つのカラー球からなる 3D マーカーを用意し, その位置・姿勢を遺伝的アルゴリズム (Genetic Algorithm. 以下 GA）によってオンラインで計算させ, 適合度の最も高い遺伝子が持つ位置・姿勢情報を水中ロ ボットが認識した $3 \mathrm{D}$ マーカーの位置・姿勢として利用する方法である. 他手法と異なる点は, (1)3D マーカーを 複眼で認識している点（Song et al., 2010）と，(2) 動画像中の画像とモデルとの相関をGA の進化における適合 度として用いることで対象物の位置・姿勢を実時間で計測している点（Suzuki and Minami, 2005, Nishimura et al., 2013）である. さらに，動画像中の GA の収束性能に関する検証（Yu et al., 2013）も行っている.

AUV を用いたドッキング制御に関する研究は広く行われており, 視覚情報を用いたアプローチも多く存在する. その中で，単眼カメラを用いた方法（Park et al., 2009, 石井他, 2015）と， ステレオカメラを用いた方法（Ura et al., 2005, Palomeras et al., 2014a, 2014b）に大別される. 石井らは, 超音波および単眼カメラを用いて水中給電へ向け たドッキングを制御誤差 $\pm 100 \mathrm{~mm}$ の精度で実現している（石井他，2015）。また，ステレオカメラを用いた研究 (Palomeras et al., 2014a, 2014b) では, ドッキング用のパネルがカメラによって検出可能な場合に, カメラ画像に よってパネルとの相対的位置・姿勢を検出し, 自動嵌合を達成している. この方法では, ステレオカメラが搭載 されているものの, そのうちの一つがパネルの位置・姿勢を推定するために用いられており, 二つのカメラが同一 対象物を同時に見ているわけではない, 具体的には, 単眼カメラによって得られたパネルに写った画像から特徵 点を抽出し，マッチングを行うことでパネルの位置と姿勢を推定している.

複眼カメラの 2 次元画像情報から対象物の 3 次元位置・姿勢を計測する情報処理では, 困難な問題が発生する. すなわち 3 次元空間内の物体上のある点が複眼カメラ画像の中のどの点に対応しているかという「対応点の同一 性」の問題である. エピポーラ幾何を用いて複眼カメラ画像内の対応点を探す方法が一般的（松山他, 1998）, (徐, 辻, 2005) であるが, 対応点の同一性が満たされない場合, 対象物の 3 次元位置・姿勢情報は誤差を含む (中原他, 2001), (小野他, 2013) ことになる.

しかしながら複眼を用いた 3 次元画像認識は, 左右両眼の視差を空間認識に利用できる単眼には無いメリットを 持っている.したがって複眼の視差を利用するメリットを持ちつつ, 対応点問題を回避する方法を考える必要があ る.この点について著者は, 3 次元立体モデルを空間内に設定し, そのモデルの左右カメラ画像への写像と実際の対 象物の左右カメラへの写像の相関を最大化する 3 次元対象物の位置 - 姿勢を求める問題を時变多峰性分布関数の最 適化問題として取り扱い, Real-time Multi-step GA (RM-GA) という手法を用いて解くことを提案した (Lwin et al., 2016). 研究の初期はビデオレートの 33ms の間に 1 回ないし数回の GA の進化計算を行うことができなかったが, 最近は計算機の性能の向上で 9 回進化させることができるようになった. さらに実時間 3 次元空間認識を用いた制 御手法を Three Dimensional Move on Sensing (3D-MoS)(見浪他, 2015) と呼び研究を続けている. 提案する 3D-MoS システムは, 3 次元形状マーカーモデル上に点群を配置しこの 3 次元点群を左右カメラ画像面に射影し, 画面上に 射影されている実際の 3 次元マーカーとの相関に基づき対象物の認識を行うために, 複眼カメラシステムの上記の 「対応点の同一性」の問題は発生しない. この特徵は, 従来の立体画像認識 ((徐, 辻, 2005), (松山他, 1998)) に記載さ れているような 2 次元複眼画像から 3 次元情報を復元する方法ではなく, 対象物の 3 次元モデルを 2 次元の複眼画 像面へ射影 (順方向射影) しその射影モデルと画像内の認識対象物の画像情報の相関を用いて 3 次元モデルの位置・ 姿勢を求める (宋他, 2010; 宋, 見浪, 2010) ことから得られる利点である.

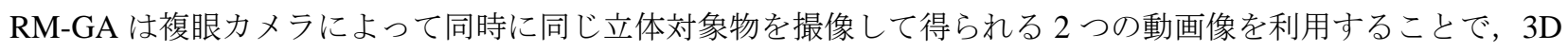
マーカーとROV との相対的位置・姿勢を認識し，3D-MoS によって水中自動給電を想定した嵌合実験に大学内の 簡易プールで成功した（矢納他, 2015, Myo et al., 2015）が，プール環境では提案したシステムの実用上の有効性 の評価は十分ではない，そこで，本嵌合システムの実海域での有効性を確認するため，和歌山県の湾内で直径 70 $\mathrm{mm}$ の円筒に $8 \times 6 \mathrm{~mm}$ の嵌合棒を嵌合させる実験を行った．本報では，この実験の結果を水中ロボットの運動解 析と実時間 3 次元位置・姿勢認識の時系列データと共に報告する. 


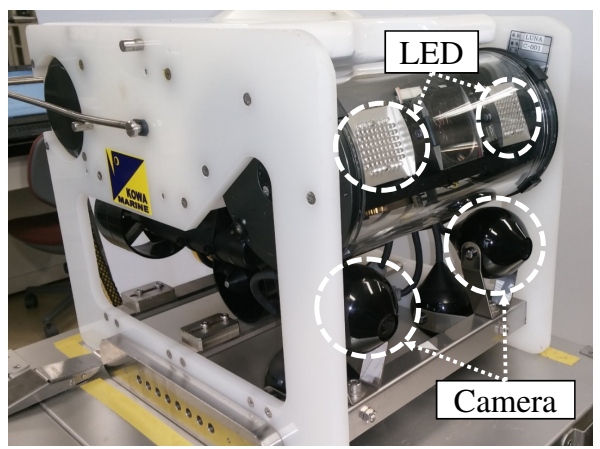

Fig. 1 ROV.
Table 1 Specification of ROV.

\begin{tabular}{|c|c|}
\hline Maximum operating depth $[\mathrm{m}]$ & 50 \\
\hline Dimension $[\mathrm{mm}]$ & $280(\mathrm{~W}) \times 380(\mathrm{~L}) \times 310(\mathrm{H})$ \\
\hline Dry weight $[\mathrm{kg}]$ & 15 \\
\hline Number of thrusters & 2(Horizontal), 1(Vertical), 1(Traverse) \\
\hline Number of cameras & 2 (Front, fixed), 1 (Tilting and zooming) \\
\hline Number of LED & $2(5.8[\mathrm{~W}])$ \\
\hline Tether cable $[\mathrm{m}]$ & 200 \\
\hline Structure materials & Aluminum alloy and acrylate resin \\
\hline Maximum thrust force $[\mathrm{N}]$ & 9.8 (Horizontal).4.9(Vertical, Traverse) \\
\hline
\end{tabular}

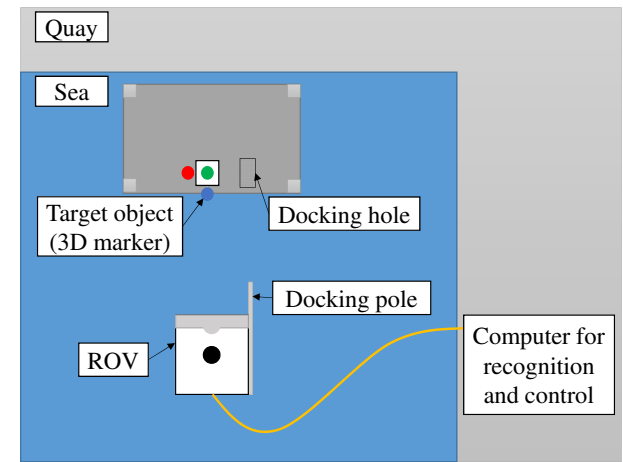

Fig. 2 Layout of docking experiment(top view).

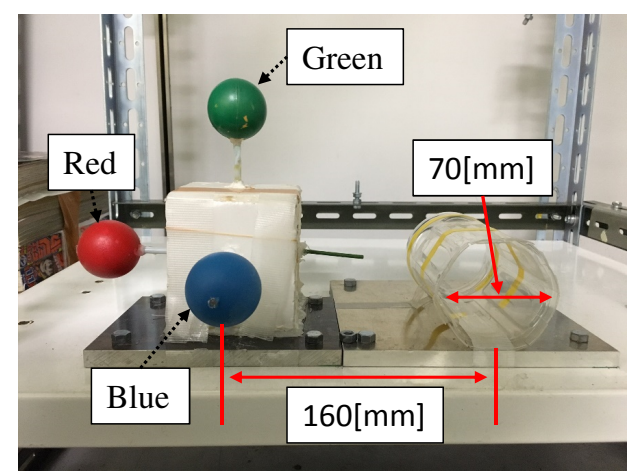

Fig. 3 Virtual recharging station with docking hole and 3D marker.

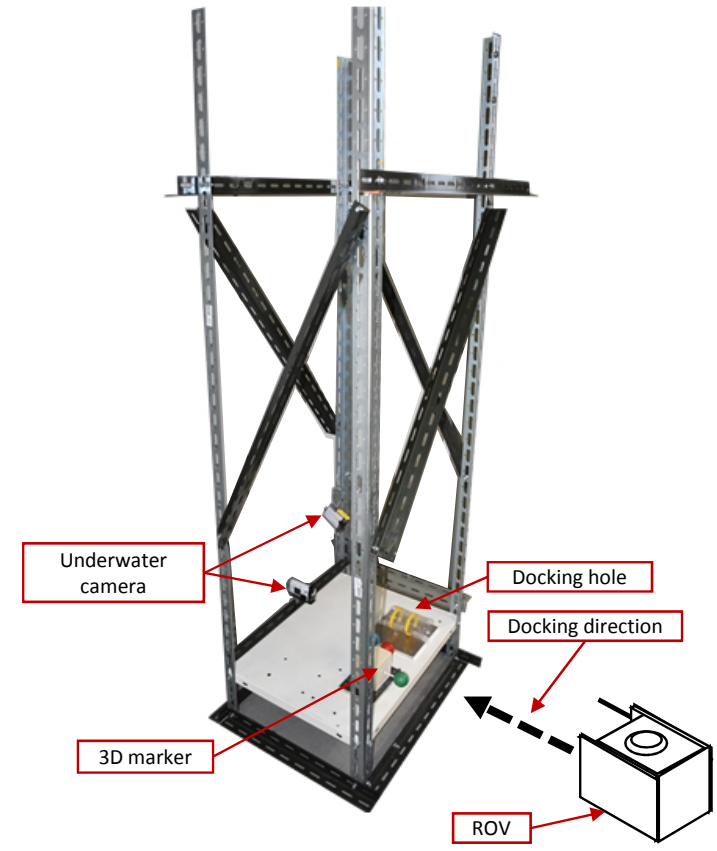

Fig. 4 Structure of virtual recharging station.

\section{2. 実海域嵌合実験}

既報 (矢納他,2015) での実験はプールでの嵌合実験であった.このため提案手法の実用上の有効性を評価するた め実海域環境で嵌合実験を行うことにした. 認識系, 制御系は既報 (矢納他,2015) と同じである. 気象条件により変 化する日照条件, 嵌合ステーションの岸壁の海藻, 貝などで作られる自然な背景に対する認識系の有効性を確認す ること,さらにこの認識系を用いたビジュアルサーボ系が実海域に存在する海水の動摇を抑えて安定化させること が可能か否かについて確認することが目的である. 嵌合実験の成功によって港湾内の自然環境でビジュアルサーボ の安定性と嵌合制御の有効性を確認することができた. 以下では実海域における実験環境等について述べる.

\section{$2 \cdot 1$ 実験環境}

本実験は 2015 年 12 月 16 日午後 2 時頃，和歌山県有田郡広川町の港湾内で実施した。水深は約 $3.5 \mathrm{~m}$ ，天候は くもり，風はあったが波は穏やかな状況であった。実験に用いた ROV (広和 (株) 製) を図 1 に，その仕様を表 1 に示す. また実験における対象物（3D マーカー）と嵌合穴，ROV を上方から見た港湾内のレイアウトを図 2 に 
示す. 図 2 は上方と右側が岸壁であり, Sea と表記された部分が海である.また, 図 3 に示す $3 \mathrm{D}$ マーカー及び嵌 合穴を図 4 の構造物の底部に固定し，それらを水深約 $3 \mathrm{~m}$ の位置に沈めて設置した. 図 3 に示すように，3Dマー カーは赤・青・緑色のカラー球から構成される. 嵌合穴の直径は $70 \mathrm{~mm}$ であり, 3D マーカーの中心と嵌合穴の中 心との距離は $160 \mathrm{~mm}$ である. 図 4 は嵌合穴, 3D マーカー, 記録用カメラを水中に固定設置するためのトラス構 造物である. 淡水と海水による浮力の差に対応するため, 実験を行う前に水中ロボットにおもりをつけることで 浮力調整を行った.

\section{$2 \cdot 2$ Real-time Multi-step GA}

動画像列の中で対象物を認識しその位置・姿勢を計測することは, 時変多峰性分布関数の実時間最適化問題を 解くことと等価となる（Suzuki and Minami, 2005）. $33 \mathrm{~ms}$ 毎に新しい画像が入力され, 次の画像が入力されるま での時間に最適化問題を解く必要がある.ここで，(1) 計算時間の短い単純な GA の進化回数を多くすべきか, (2) 計算時間が長いがより高度な手法を用い, 繰り返し回数が少ない方法にす心゙きかという戦略の選択肢が考えられ るが，本研究は (1) を用いて対象物の位置・姿勢の実時間計測を行っている. 以前の研究では，ビデオレートであ る $33 \mathrm{~ms}$ 毎に入力される動画像を, 次の画像が入力されるまでの時間で GA による Model-based Matching を行っ ていた. さらに動画像列の中で GA の遺伝子を進化させて画像列に写っている対象物にモデルを収束させること で，対象物の位置・姿勢を実時間で計測する手法を用いていた。また $33 \mathrm{~ms}$ の間に一回の進化を行うことしかで きなかったため「1-Step GA」と呼んでいた（Suzuki and Minami, 2005）。1-Step GA で動画像の認識を行うことが できるが，最近のコンピュータの性能の向上により複数回進化できるようになり，動画像中で移動する対象物の 位置・姿勢計測精度および認識の時間応答が改善された。そこで，この認識法を「Real-time Multi-step GA」（以 下，RM-GA と表記）と呼ぶことにする. RM-GA では遺伝子に与えている6つの情報（位置・姿勢）を，それぞ れ 12 bit で定義している. 図 5 の左側には，3 次元モデルが探索空間内の対象物に収束していく流れが描かれてい る. 図 5 右側のフローチャートに示すように, ビデオレート (33 ms) で画像入力を繰り返し, 新たな入力画像に 対する認識の際, 直前の優秀な遺伝子（適合度が高い值を示す遺伝子）が引き継がれるエリート保存戦略を採用 している.このため, 動画像列の中で $3 \mathrm{D}$ マーカーを見失うことなく実時間での位置・姿勢計測を実現している. 左右のカメラの $640 \times 480$ 画素それぞれについて RGB 值を入力し, それらの值から HSV 表色系の H の值を算出 しこれをもとに適合度関数を計算している (Lwin et al., 2016). したがって画像の変換を行うフィルター処理を行っ ていない. 画像入力ボード (インターフェイス社製 PCI-5523) の左右 2 枚の画像をメモリ一空間に転送するのに要 する時間は $9 \mathrm{~ms}$ である. したがって $24 \mathrm{~ms}(=33-9)$ の間に 9 回の進化を行うことができるので, 1 世代約 $2.7 \mathrm{~ms}$ で進 化している.

図 6 に 3D マーカーを示す. 赤青緑の球を立体的に構成したマーカーであり, マーカーと適合度関数の計算方法 は (Lwin et al., 2016) に示されている. 遺伝子の評価は, 3 次元で定義されたモデルの位置・姿勢情報を基に, 3 次 元空間から 2 次元画像に射影されたモデルと $3 \mathrm{D}$ マーカーとの相関（適合度関数として定義）を評価することで行 われる. さらに左右画像での 3D マーカーとモデルとの相関值の平均を複眼カメラでの相関值と定義し（Song et al., 2010, Nishimura et al., 2013），適合度関数として用いることで左右カメラの視差を考慮した立体認識を構成し ている．遺伝子は初期状態では，図 5 の左側の 1 st generation に示すようにランダムに散りばめられる.それらの 遺伝子に対して適合度関数を用いてモデルの位置・姿勢の評価を行い, その後選択，交叉，突然変異を行う。本 実験で使用したコンピュータ（Processor：Intel(R) Core(TM) i7-4790 CPU @ 3.60GHz, RAM:8.00 GB）の場合, 33 ms 内の RM-GA の進化回数は 9 回であった. RM-GA のパラメータを表 2 に示す.

\section{$2 \cdot 3$ 嵌合制御シーケンス}

嵌合を行う上で，4つの動作状態を定義する。それぞれ (a)Manual Operation（手動操作による仮想給電設備へ の接近）, (b)Visual Servoing（3D マーカーへの正対）, (c)Docking（嵌合）, (d)Docking Completion（嵌合完了）で ある.

\section{(a) Manual Operation}

ロボット前方に搭載された複眼カメラに対象物が映し出されるまで，ロボットを手動操作で接近させる。ロ ボットを対象物にある程度接近させた後, RM-GAにより決定される最大適合度を示す遺伝子の位置・姿勢情 


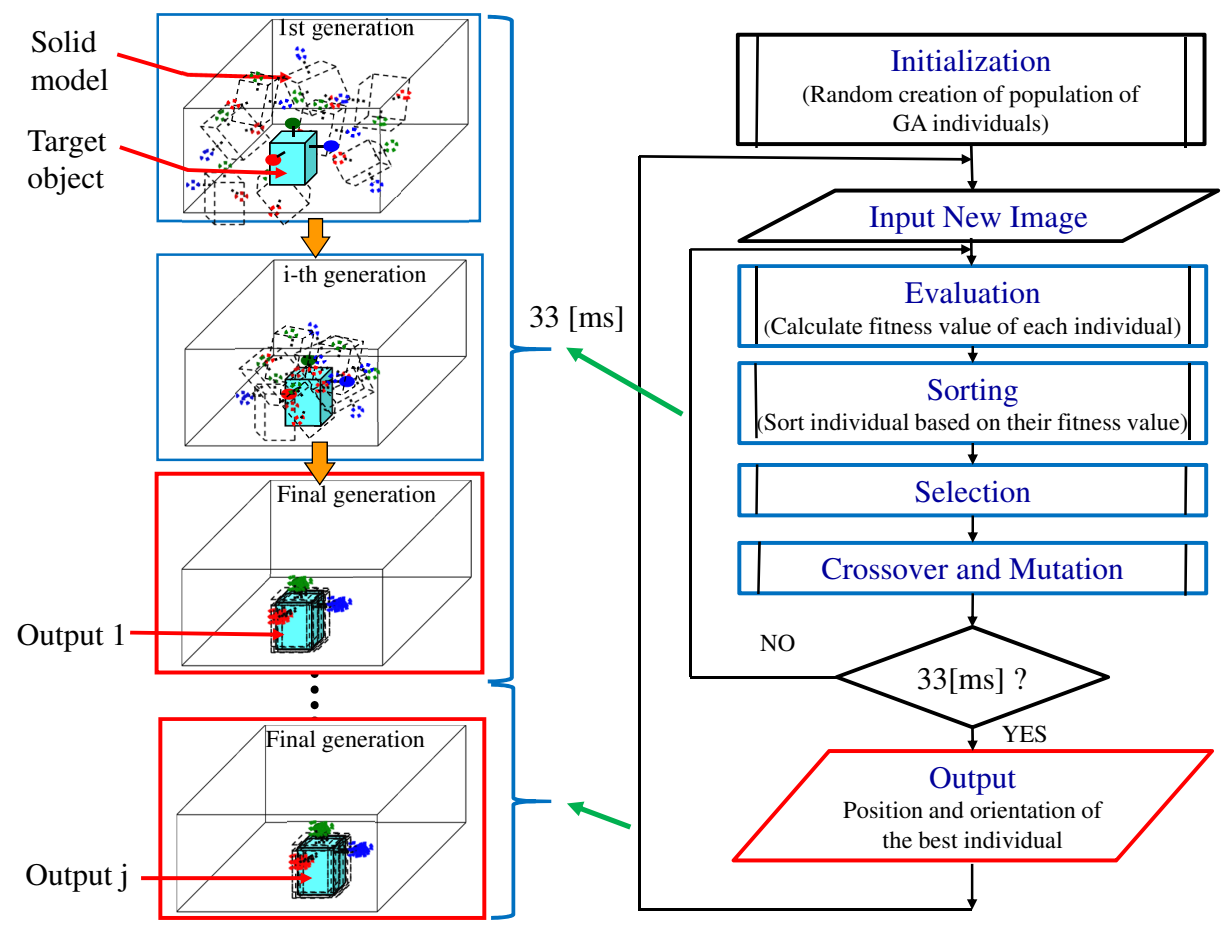

Fig. 5 Flowchart of Real-time Multi-step GA to track pose of ROV.

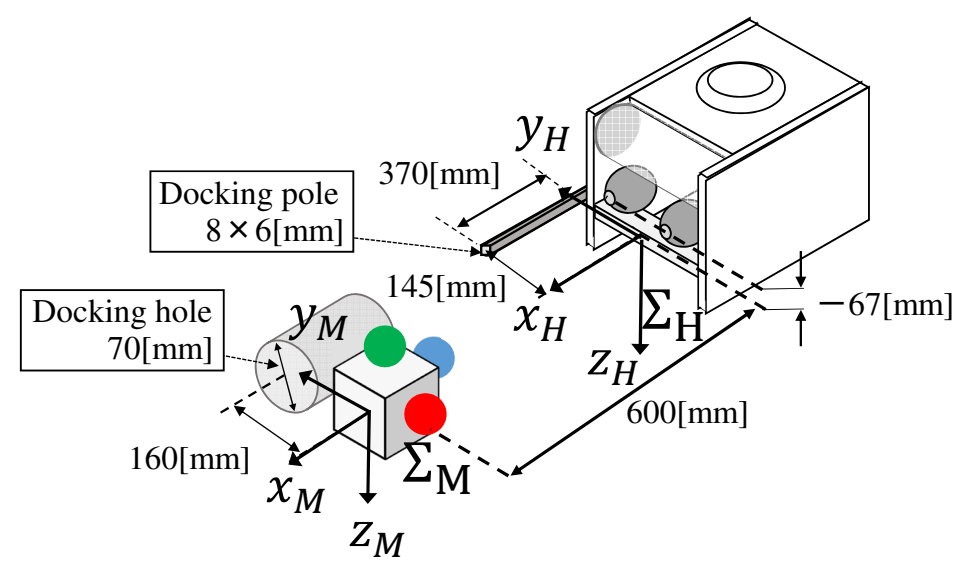

Fig. 6 Coordinate system of ROV and virtual docking station.

報を持つモデル（ビジュアルサーボによる嵌合の様子を示寸図 9 において破線で表示された 3 つの円）と左 右カメラに映し出された 3D マーカーとが重なって表示され, 適合度の值が 0.6 以上に上昇したことが確認さ れた後（図 9(b)，(c)，(d)において破線の円が 3D マーカーに重なって表示されていることが，位置・姿勢の 計測が正しくされていることを示す) に，手動操作から自動制御へ切り替えることで(b)Visual Servoing 状態 一移行させる.

(b) Visual Servoing

$\mathrm{ROV}$ が 3D マーカーを発見し，目標とする相対的位置・姿勢（図 6 に示す $\Sigma_{H}$ を基準に， $\left[x_{d}, y_{d}, z_{d}\right]=[600$, 12，-70 $] \mathrm{mm}$. 姿勢はクォータニオンで表現し， $\left.\varepsilon_{d}=\left[\varepsilon_{1}, \varepsilon_{2}, \varepsilon_{3}\right]=\left[\begin{array}{lll}0, & 0,0\end{array}\right]\right)$ に追従することで対象物と正対 する状態である. ここで, $\varepsilon_{1}, \varepsilon_{2}$ は図 6 に示す $\Sigma_{H}$ の $x_{H}, y_{H}$ 軸周りの姿勢であるが，重心と浮心の関係によ り安定に 0 に保たれている. $y_{d}=12 \mathrm{~mm}$ と設定した理由は, $3 \mathrm{D}$ マーカーと嵌合穴との位置, および $\Sigma_{H}$ 原点 と嵌合棒との位置関係のオフセットを調整するためであり, $z_{d}=-70 \mathrm{~mm}$ は, 図 6 の $\Sigma_{M}$ 原点と嵌合穴の中心 位置との位置関係に基づいて, カメラの $z_{H}$ 軸位置 $\left(z_{d}=-67 \mathrm{~mm}\right)$ から実験時に $3 \mathrm{~mm}$ 調整した結果である. ROV が 3D マーカーの正面に移動し, 嵌合穴の中心から $y_{H}$ 軸, $z_{H}$ 軸方向の誤差が $\pm 20 \mathrm{~mm}$ 以下に留まる状 
Table 2 Parameters of Real-time Multi-step GA.

\begin{tabular}{|c|c|}
\hline Number of genes & 60 \\
\hline Evolved pose (position and orientation) & $\begin{array}{r}\left(x, y, z, \varepsilon_{1}, \varepsilon_{2}, \varepsilon_{3}\right), \text { all genes are coded by binary } 12 \text { bits } \\
\left(\varepsilon_{1}, \varepsilon_{2}, \varepsilon_{3}\right) \text { are represented by quaternion }\end{array}$ \\
\hline $\begin{array}{c}\text { Pose used for controlling } \\
\text { (Position, Orientation) }\end{array}$ & $\begin{array}{c}\text { Position }(x \mathrm{~mm}, y \mathrm{~mm}, z \mathrm{~mm}) \\
\text { Orientation }\left(\varepsilon_{3}\right) \text { around z-axis of } \Sigma_{H} \text { in Fig.6 }\end{array}$ \\
\hline Searching space defined by $\Sigma_{H}$ in Fig.6 & $\left\{\mathrm{x}, \mathrm{y}, \mathrm{z}, \varepsilon_{3}\right\}=\{ \pm 400, \pm 400, \pm 200, \pm 0.15($ equal to \pm 17.3 degree $\}$ \\
\hline Control period [ms] & 33 \\
\hline Number of gene evolution [times/33ms] & 9 \\
\hline Selection rate [\%] & 60 \\
\hline Mutation rate [\%] & 10 \\
\hline Crossover & Two-point \\
\hline Evolution strategy & Elite preservation \\
\hline
\end{tabular}

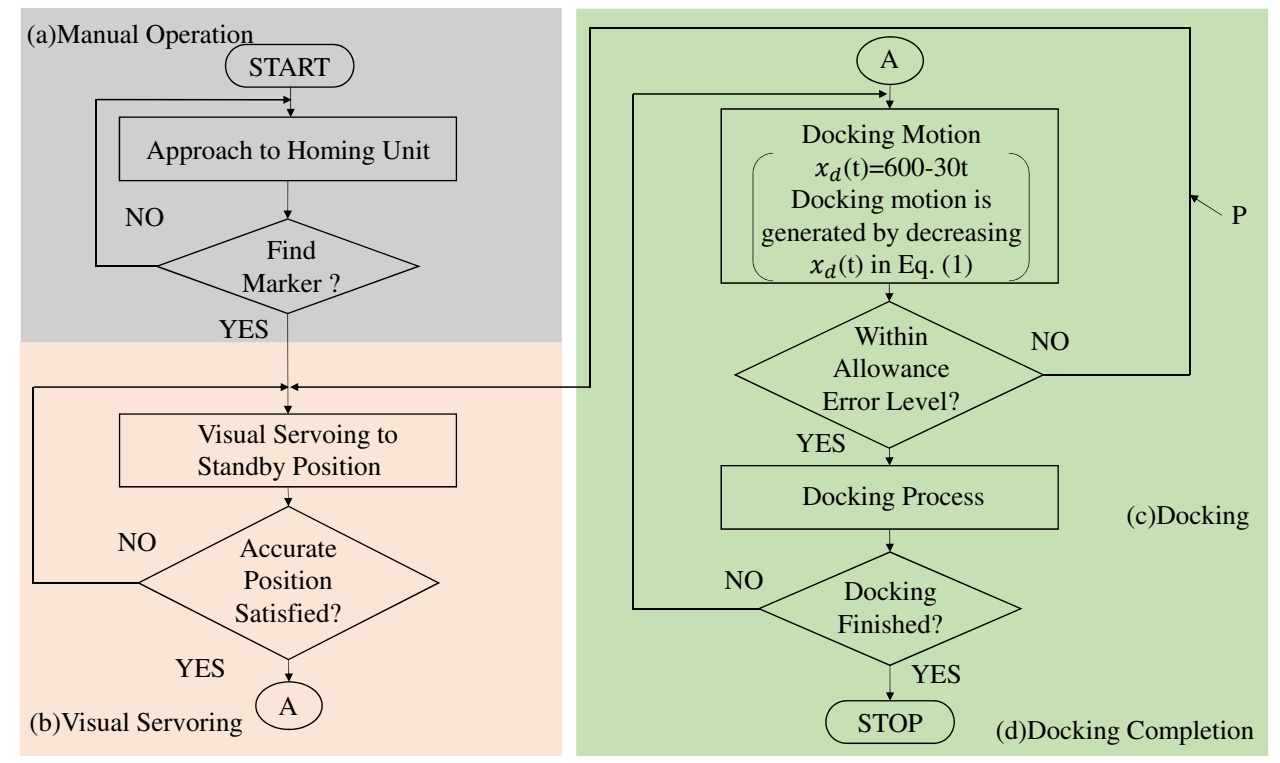

Fig. 7 Flowchart of docking strategy.

態が 165 ms 連続すると以下に示す (c)Docking を経てロボットは仮想給電設備への嵌合を実行する．以下は， ROV に推力を発生させるための, 出力電圧を決定する制御式である.

奥行き方向 : $v_{1}=k_{p 1}\left(x_{d}-x\right)+2.5$

$\left(v_{1}=0 \mathrm{~V}\right.$ のとき $\Sigma_{H}$ の $x_{H}$ 軸方向に推力 $9.8 \mathrm{~N}, v_{1}=5 \mathrm{~V}$ のとき $\left.-9.8 \mathrm{~N}\right)$

鉛直軸回転 : $v_{2}=k_{p 2}\left(\varepsilon_{3 d}-\varepsilon_{3}\right)+2.5$

$\left(v_{4}=0 \mathrm{~V}\right.$ のとき $\Sigma_{H}$ の $z_{H}$ 軸回りに旋回トルク $0.88 \mathrm{Nm}, v_{4}=5 \mathrm{~V}$ のとき $\left.-0.88 \mathrm{Nm}\right)$

鈆直方向: $\quad v_{3}=k_{p 3}\left(z_{d}-z\right)+2.5$

$\left(v_{3}=0 \mathrm{~V}\right.$ のとき $\Sigma_{H}$ の $z_{H}$ 軸方向に推力 $-4.9 \mathrm{~N}, v_{3}=5 \mathrm{~V}$ のとき推力 $\left.4.9 \mathrm{~N}\right)$

水平方向: $v_{4}=k_{p 4}\left(y_{d}-y\right)+2.5$

$\left(v_{4}=0 \mathrm{~V}\right.$ のとき $\Sigma_{H}$ の $y_{H}$ 軸方向に推力 $-4.9 \mathrm{~N}, v_{4}=5 \mathrm{~V}$ のとき推力 $\left.4.9 \mathrm{~N}\right)$

式中のゲインは, $k_{p 1}=0.005 \mathrm{~V} / \mathrm{mm}, k_{p 2}=1.3 \mathrm{~V}, k_{p 3}=0.04 \mathrm{~V} / \mathrm{mm}, k_{p 4}=0.035 \mathrm{~V} / \mathrm{mm}$ と事前の予備実験に より設定した. 
(c) Docking

ROV が前進して嵌合動作を行っている状態である. $\left|y_{d}-y\right| \leq 20 \mathrm{~mm}$ かつ $\left|z_{d}-z\right| \leq 20 \mathrm{~mm}$ を満たすとき， 奥行き方向の目標值を $x_{d}=600-30 t \mathrm{~mm}(t$ : 嵌合を始めたときを $t=0$ とする時間 $\mathrm{s})$ と時変で減少させるこ とで ROV が $30 \mathrm{~mm} / \mathrm{s}$ の速度で $x$ 軸方向に前進し嵌合穴に嵌合する． $x_{d}$ が最終值 $350 \mathrm{~mm}$ となることで嵌合 を完了する位置に ROV が移動する．ただし途中で嵌合の条件（ $y$ 軸， $z$ 軸方向の誤差が $\pm 20 \mathrm{~mm}$ 以下）を満 たさなくなった場合，その時点での $x$ 軸方向の時変目標值を固定して再び (b)Visual Servoing に戻る．図 7 に 嵌合における (a)〜 (d) の遷移フローチャートを示す. 図中 “P”で表す経路が (c)Docking を中断して (b)Visual Servoingに戻る経路である.

(d) Docking Completion

嵌合が完了した状態である。この状態でも Visual Servoing 状態と同様に 3D マーカーに対して一定の相対 的位置・姿勢 $\left(\left[x_{d}, y_{d}, z_{d}\right]=[350,12,-70] \mathrm{mm}, \varepsilon_{d}=\left[\begin{array}{ll}0,0 & 0\end{array}\right] \mathrm{mm}\right)$ を保つように制御がなされる.

\section{3. 実 験 結 果}

\section{$3 \cdot 13$ 次元認識性能}

奥行き方向（図 6 に示す $\Sigma_{H}$ の $x_{H}$ 軸方向）の認識性能の評価を行うため, 嵌合完了時の左右カメラ画像に対す る全探索の結果と RM-GA の認識結果との比較を行う. 3D マーカーモデルの 3 次元位置・姿勢の中で， $z$ 軸位置， 姿勢 $\varepsilon_{3}$ については画像を取得した瞬間の RM-GA の認識結果に固定し, 3D マーカーの 3 次元空間上の $x, y$ 軸位 置を領域全体でスキャンすることで適合度関数の分布を調べた結果を図 8(a) に, 図 8(b) には $x$ - $y$ 平面に射影し た適合度分布とその時刻での認識值（RM-GA の最適解）を示している.

全探索では, 探索領域内の全ての解の可能性を調べ最適解を出力することが可能であるが, 時間を要するため実 時間認識には適用が困難である. RM-GA の最適化の繰り返し計算は, 遺伝子の持つ位置・姿勢の適合度の值に基 づいて進化を進めるもので, 図 8 に示寸適合度分布を算出しない. 図 8(b) から分かるように, 全探索の最適解と, RM-GAによる認識值がおおよそ一致していることがわかる，さらに，適合度の分布は“X”の形をしていることが わかる. これは, 左カメラ及び右カメラ画像と 3D モデルの相関がカメラ手前方向から奥行方向に長細い分布とな り，それらの和として図 8(b) の分布が得られるためである（Nishimura et al., 2013）. 全探索によって得られた最 適解は $[x, y]=[345.0,17.0] \mathrm{mm}$ であるのに対し，RM-GAによる認識值は $[x, y]=[349.2,18.1] \mathrm{mm}$ であった．本実 験では, 嵌合対象として直径 $70 \mathrm{~mm}$ の円筒を採用しているため, 水平 $(y$ 軸）方向の誤差 $1.1 \mathrm{~mm}$ は十分許容でき る䛊差であると言える. 奥行 $(x$ 軸) 方向の認識精度に関しても， $5 \mathrm{~mm}$ 以下の誤差であるため，こちらも許容で きると考えられる.

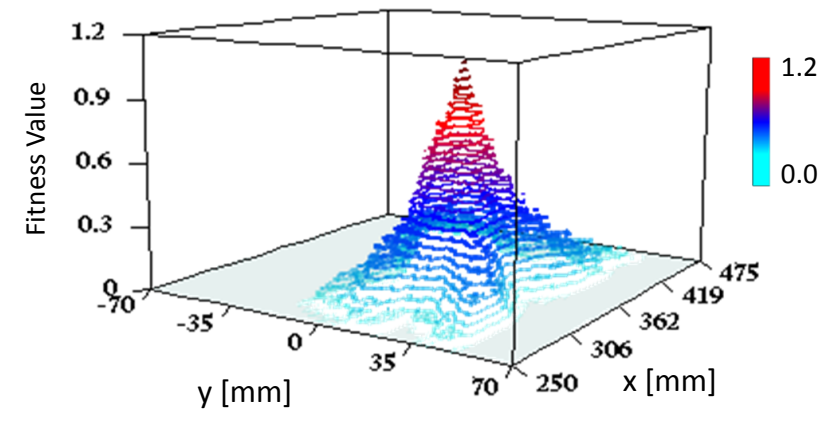

(a)

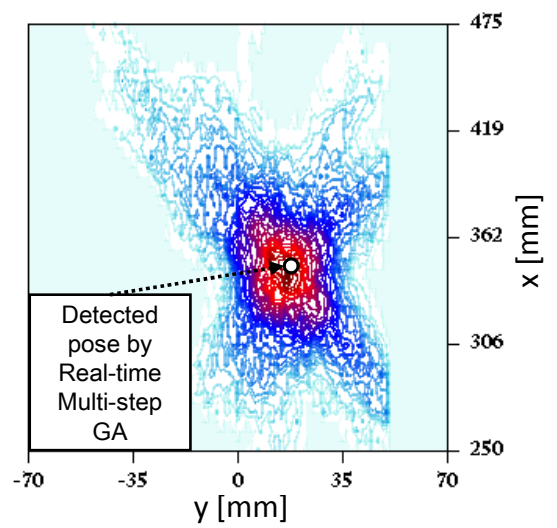

(b)

Fig. 8 Results of full search and Real-time Multi-step GA recognition, (a)fitness distribution is presented by 3D representation and (b)fitness is depicted by black/white circle with detected pose. 


\section{2 嵌合制御}

嵌合実験の画像データを図 9 に，RM-GA による認識值と時間の関係を図 10 に，実験時の静止画に対する全探 索の結果を図 11 に示す. 図 9(a)〜 (d) は，2.3 で述べた嵌合制御シーケンスの各状態 (a)〜 (d) と対応している. (a) は手動操作でROV を 3D マーカーに接近させつつ, RM-GA で 3D マーカーを探索している状態である. このと き, 左右カメラ画像内の破線で表示された最大適合度值を与える 3D モデルの位置が，3D マカーーに一致してい ないことが確認できる. (b) はビジュアルサーボによって定位置・姿勢制御を行っている状態である. (c) は嵌合中 の様子であり，(d) は嵌合が完了した後のビジュアルサーボの様子を示している. (d) の画像から, 嵌合棒が円筒の 中に入っており, 目的の嵌合動作が完了していることがわかる. 図 9 の (b)〜 (d) では, それぞれ左下の左右力メラ 画像中の 3D マーカーと認識值を示す破線の円とが一致していることを確認できる．これは，RM-GAによる認識 が 3D マーカーの位置・姿勢を正しく計測していることを示している．さらに (c)，(d) では，カメラ視線方向手前 に位置する中央の青い球のモデルの破線は，他の球より円の径が大きいことがわかる．これは青の球とカメラの 距離が他の球より短いことを表しており，カメラ視線方向の位置の認識精度が向上する理由を示している.

図 10(a) は，嵌合実験において，RM-GAによりビデオレート（33 ms）で計測される認識位置をドットでプロッ トしたものである。図 10(a)の中央部分が Visual Servoing を行っている区間であり，その右側が Docking 区間であ る. Manual Operation と Visual Servoing の切り換えは，図 10(b)-1 の Fitness の值が 0.6 程度に上昇したことをオぺ レーターが制御コンピュータのCRT 上の表示で確認し，手動で行った。図 10(b) 中の時刻 (B) は Visual Servoing に切り換えた時刻を表す. 時刻 (B) 以降, 図 7 のフローチャートに従い, 自動嵌合を行う. 図 10(b)-1〜(b)-5 はそ れぞれ, 適合度, $\Sigma_{H}$ で表した ROVの位置 $(x, y, z)$, 姿勢 $\left(\varepsilon_{3}\right)$ の時間推移を示しており,すべて RM-GA の計算 結果である. また図中の “Automatic Control” は, 2.3 節の (b),(c),(d) の一連の動作を行っていることを意味する.

姿勢の認識はクオータ二オン表現を用いているが, 図 10(b)-5 では, 単位を“deg”に変換して表示している. 図 10(b)-2 では，時刻 (B)より $\Sigma_{H}$ の $x_{H}$ 座標が減少しており，Visual Servoing の目標值（[ $\left.x_{d}, y_{d}, z_{d}\right]=[600,12,-70]$ $\mathrm{mm}$ ）に対する制御が始まったことを確認できる. 時刻 $(\mathrm{C})$ で Docking が開始され，65 s で完了している． $y_{H}, z_{H}$ 軸方向に関して，嵌合穴の中心（目標值）から認識值の誤差が $\pm 20 \mathrm{~mm}$ の範囲内に留まる状態を，ROV が維持し

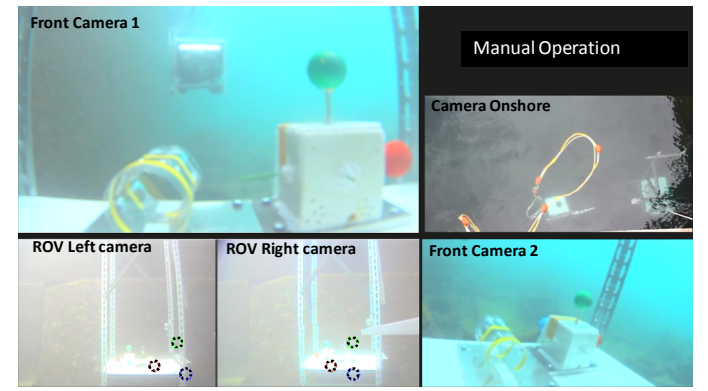

(a)

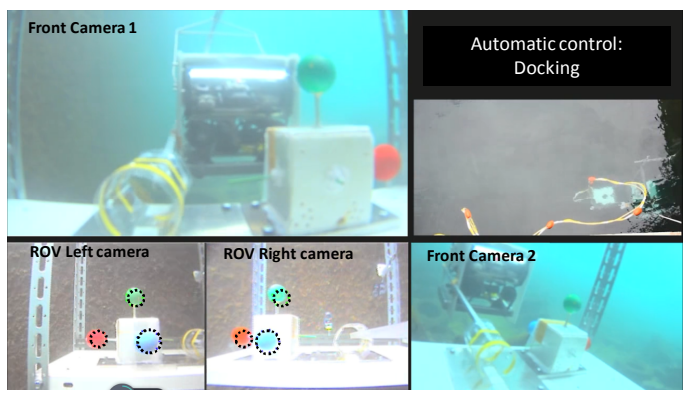

(c)

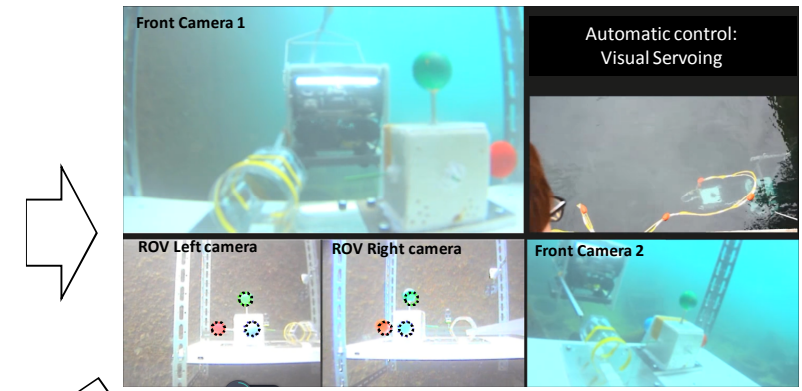

(b)

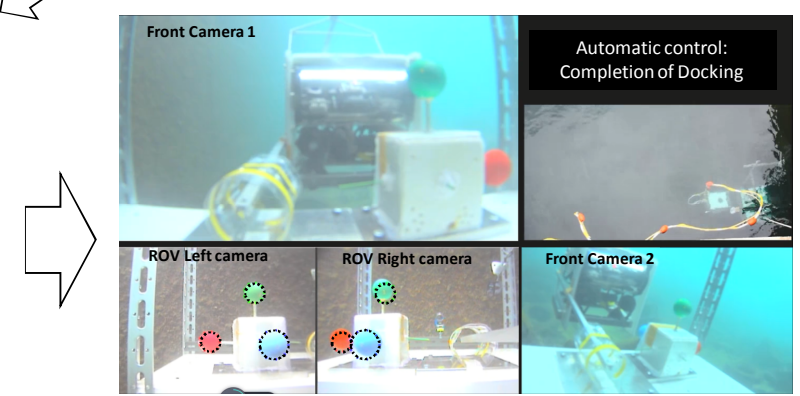

(d)

Fig. 9 Docking control sequences by dual-eye visual servoing consisting of (a)Approach by manual operation, (b)Preparation for docking that controls the pose of the vehicle to be constant desired values, (c)Docking by decreasing desired position between 3D marker and the vehicle, (d)completion of docking. Front Camera1 and front Camera2 are photos taken by cameras set at docking frame shown in Fig.4. The photos of ROV Left camera and ROV Right camera are shown in left bottom part of the group photos, with dotted circles indicating real time pose tracking results, and the photo of camera onshore shows the vehicle seen on the quay. 


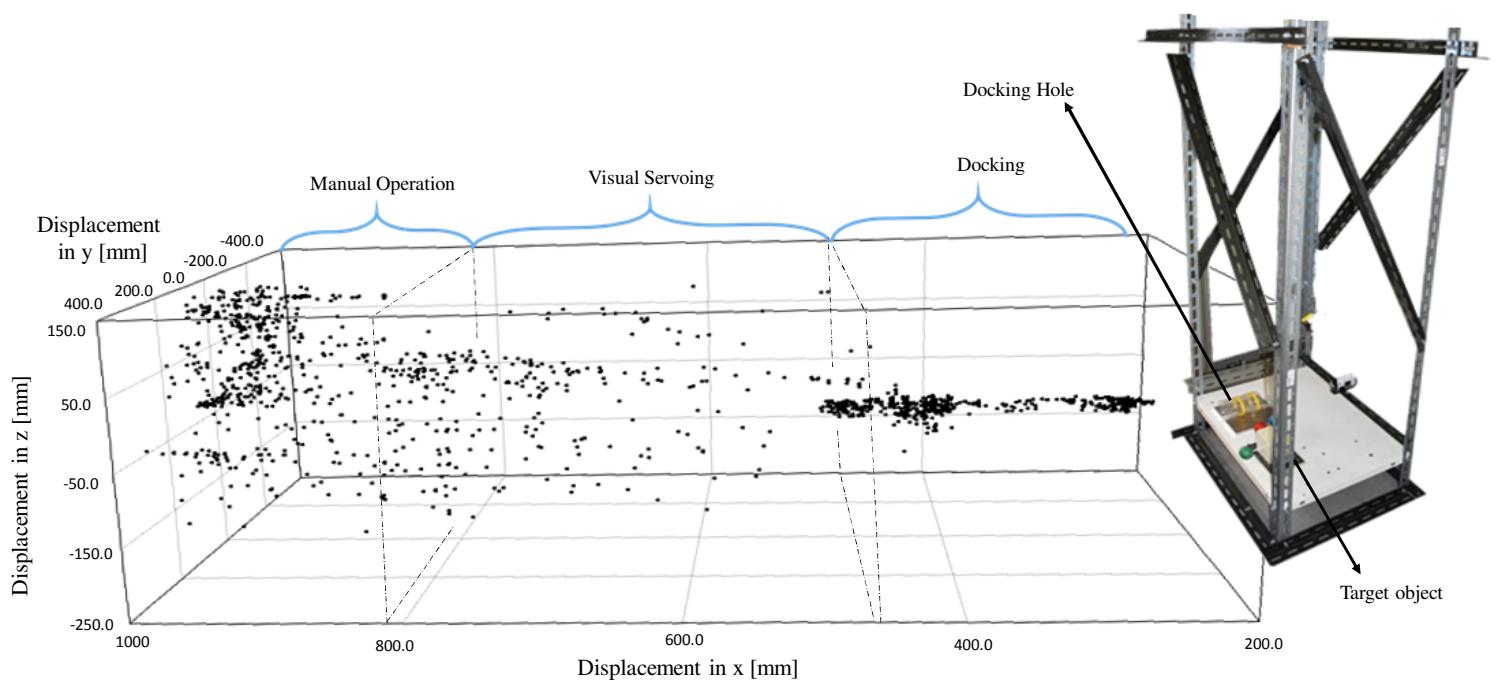

(a)Position trajectory during docking operation estimated by RM-GA

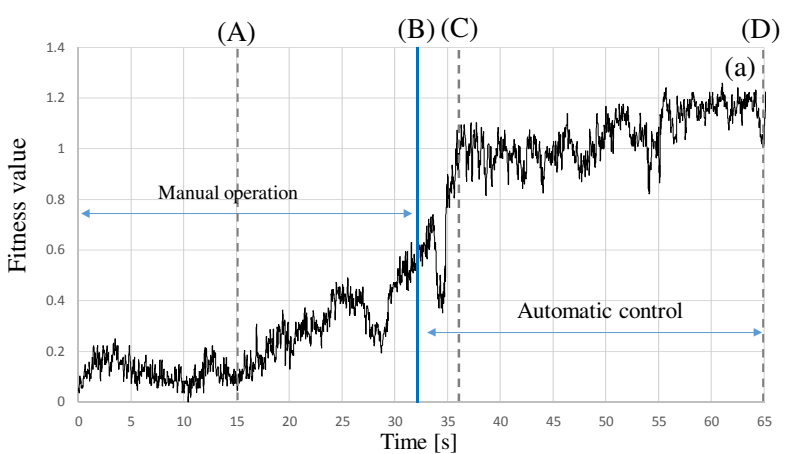

(b) -1

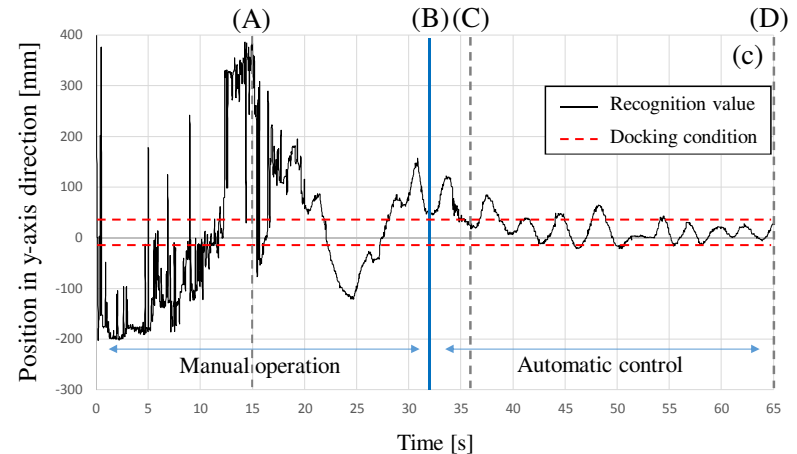

(b)-3

(A)

(B) (C)

(D)

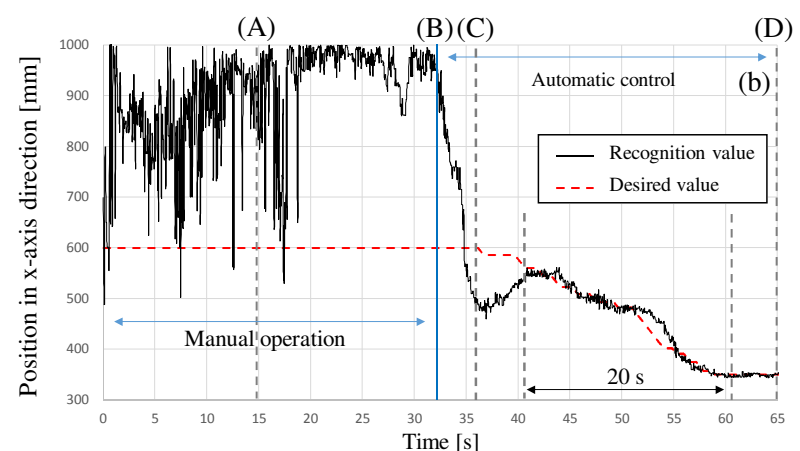

(D)

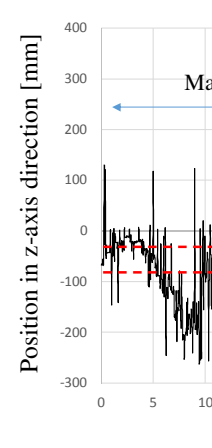

(A)

(b) -2

(B) (C)

(D)

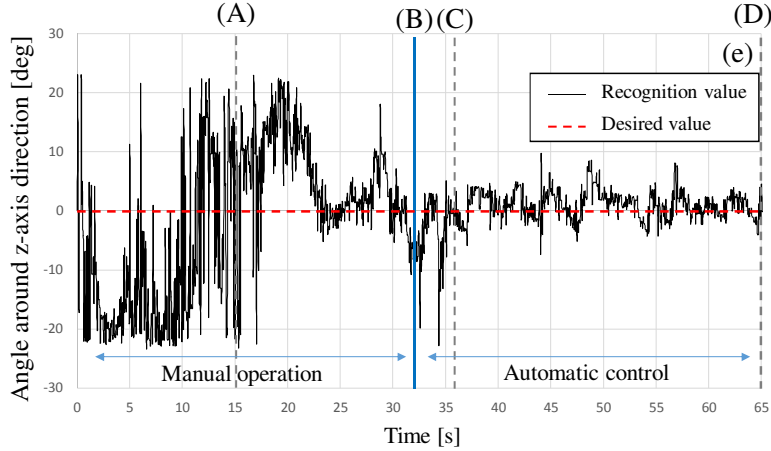

(b)-5

(b)Time profile of fitness value, position and pose during docking operation

Fig. 10 Docking result 1 : (a)Position trajectory and (b)time profile of fitness value((b)-1),recognized positions in $\mathrm{x}, \mathrm{y}, \mathrm{z}$ axes direction((b)-2,3,4) and angle around $\mathrm{z}$-axis $((\mathrm{b})-5)$. 
(A)

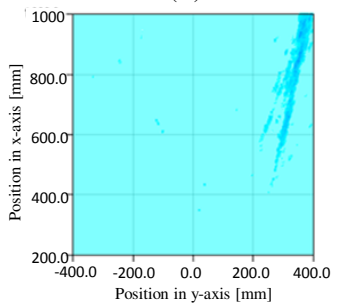

(a) -1

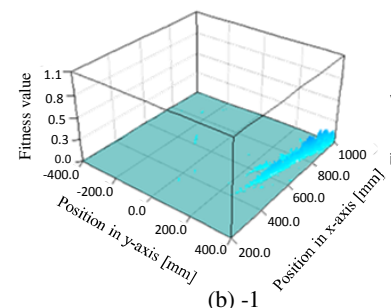

(b) -

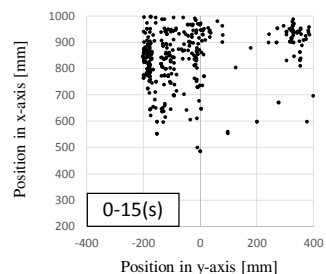

(c) -1
(B)

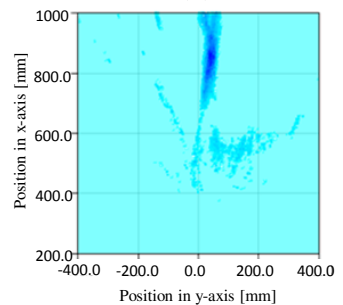

(a) -2
(C)

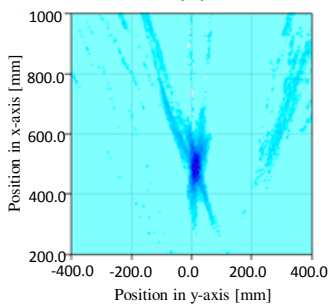

(a) -3
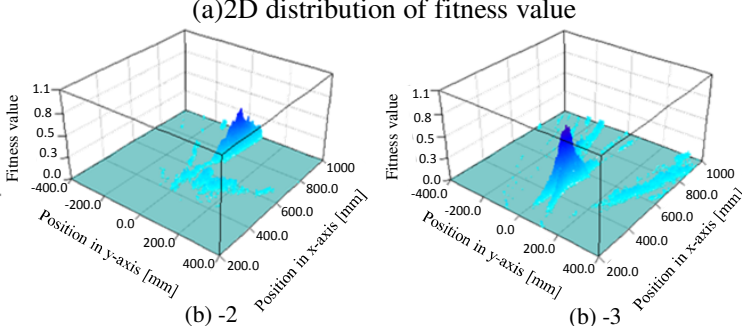

(b) -3

(b)2D distribution of fitness value

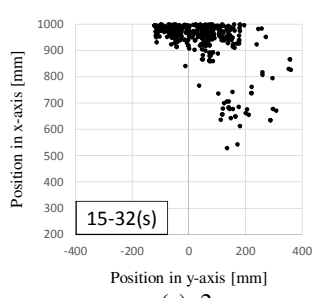

(c) -2

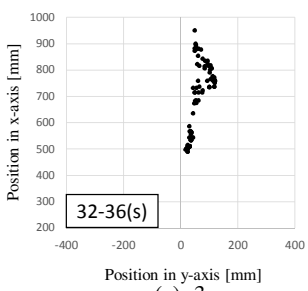

(c) -3
(D)

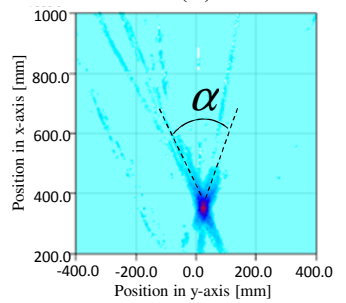

(a) -4

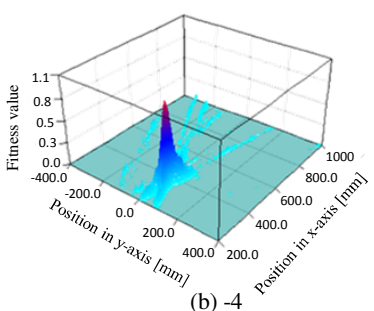

(c)Recognized positions

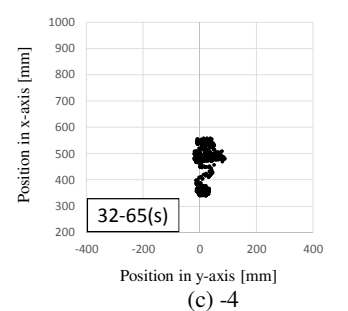

Fig. 11 (a),(b), Result of full search and (c), recognized positions during docking operation.

ている時間区間では嵌合条件を満たしている．図 10(b)-3，4 に示寸，2 本の破線に挟まれた範囲 $(-8 \leq y \leq 32$, $-90 \leq z \leq-50)$ が嵌合を実行する条件である. 時刻 (C) 以降に， $y$ 座標が嵌合条件から外れている瞬間が存在す るが，その際は図 7 の “P”ルートを通り，Visual Servoing 状態に戻る．また，図 10(b)-5 に示寸ように， $z$ 軸周り の姿勢の制御誤差は，嵌合中 $\pm 10 \mathrm{deg}$ 以下であることがわかる.

図 11 は嵌合実験において，全探索の結果とRM-GA による認識結果を表している．図中の (A)〜(D) は図 10 に 示寸時刻 $(\mathrm{A}) \sim(\mathrm{D})$ に対応している. 3.1 と同様に，3D マーカーモデルの 3 次元位置・姿勢の中で， $z$ 軸位置，姿勢 $\varepsilon_{3}$ については画像を取得した瞬間の RM-GA の認識結果に固定し， $x, y$ 軸位置を画像領域全体でスキャンすること で適合度の分布を調べた。その結果を図 11(a)，(b) に示寸．図 11(c) はそれぞれ，(c)-1:実験開始から $15 \mathrm{~s} ，(\mathrm{c})-2: 15$ 〜32 s，(c)-3:32〜36 s，(c)-4:36〜 65 s の間の $33 \mathrm{~ms}$ 毎に計測される $y ， z$ 軸方向の認識結果を全てプロットしたも のである. 図 11(a)(b) から分かるように, 時刻 (A) から (D) に移るにつれて, ROV は 3D マーカーに接近し左右力 メラの 3D マーカーに対する視差が大きくなる．この傾向は，図 11(a)-1 から (a)-4に見られる “X” 状の適合度分 布に表れている。すなわち，最も認識対象に接近している (a)-4では，“X”型分布の角度 $\alpha$ が大きくなっている. これは，適合度関数が右カメラ画像から取得した適合度と，左カメラから取得した適合度の平均で計算されるた めである（Nishimura et al., 2013）。 また, 図 11(c) に関して，(c)-1 から (c)-4 に移るにつれ， $x_{H}, y_{H}$ 軸の認識值 のばらつきが小さくなっていることが確認できる．このばらつきは ROV の動きから生じるものと，RM-GA によ る認識から生じるものの両方の原因が考えられる。(a), (b) の全探索の結果と比較すると, 適合度のピークが顕著 に表れるにつれ，認識のばらつきが小さくなっていることが確認できる．また嵌合終盤で船体の動摇が嵌合前半 に比べて抑えられていることから，ROV が 3D マーカーに近づくにつれ制御性能が安定することが分かった.

図 12〜14 は, 成功した 4 回の嵌合実験のうち，2４回目の結果である. 全ての図で，自動制御に切り替えた 後, $40 \mathrm{~s}$ 以内に嵌合が完了していることが確認できる．図 12，13 では嵌合に要した時間は $10 \mathrm{~s}$ 程度であるが，図 10 では $20 \mathrm{~s}$, 図 14 では $23 \mathrm{~s}$ 程度を要した。これらの嵌合では, 図 7 に示す“P”のルートで嵌合状態からビジュ アルサーボ状態に戻る状態推移が発生したためと考えられる。 

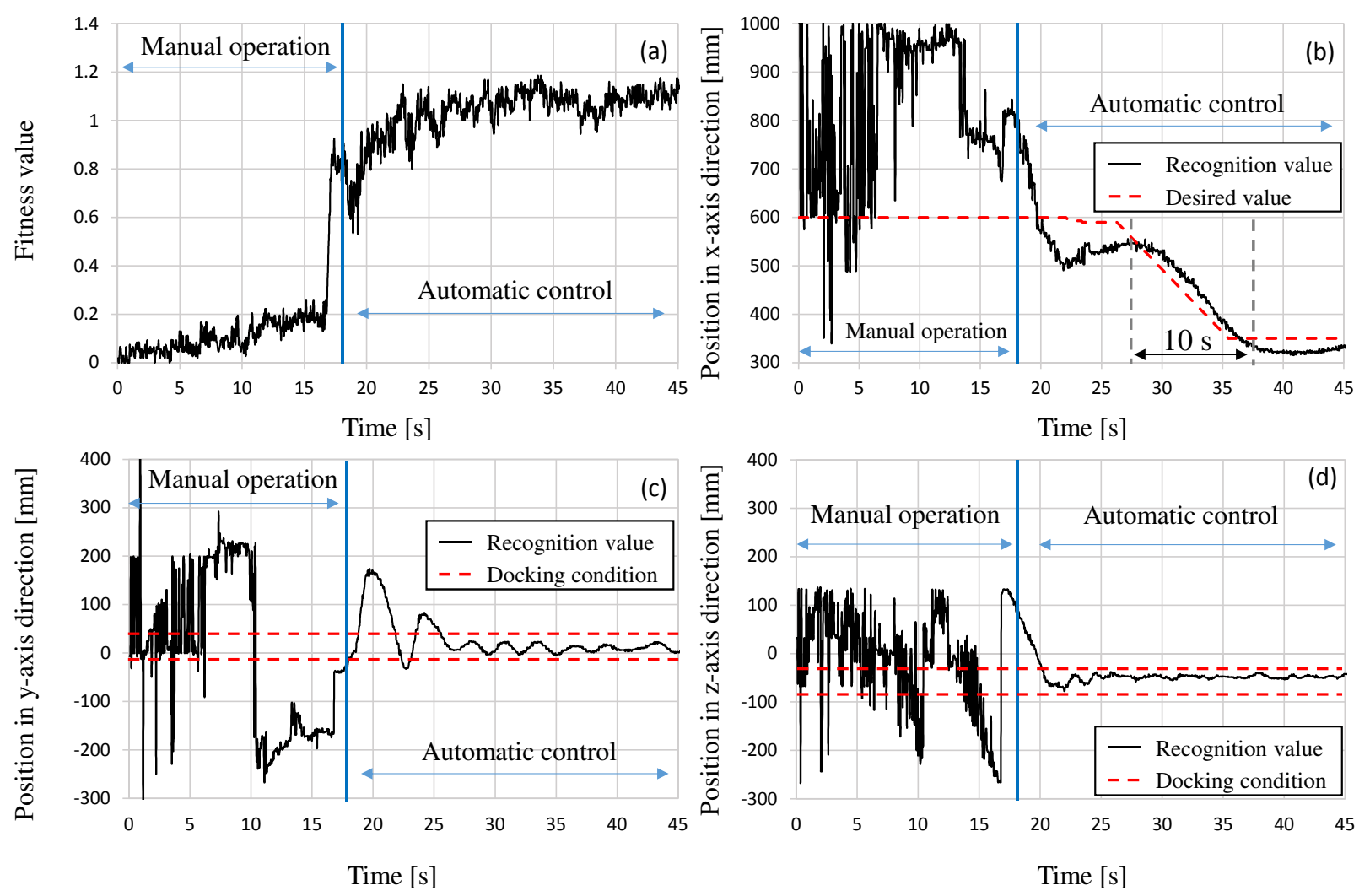

Fig. 12 Docking result 2 : (a)fitness value, (b)(c)(d)recognized positions in $\mathrm{x}, \mathrm{y}$ and $\mathrm{z}$ axes direction.
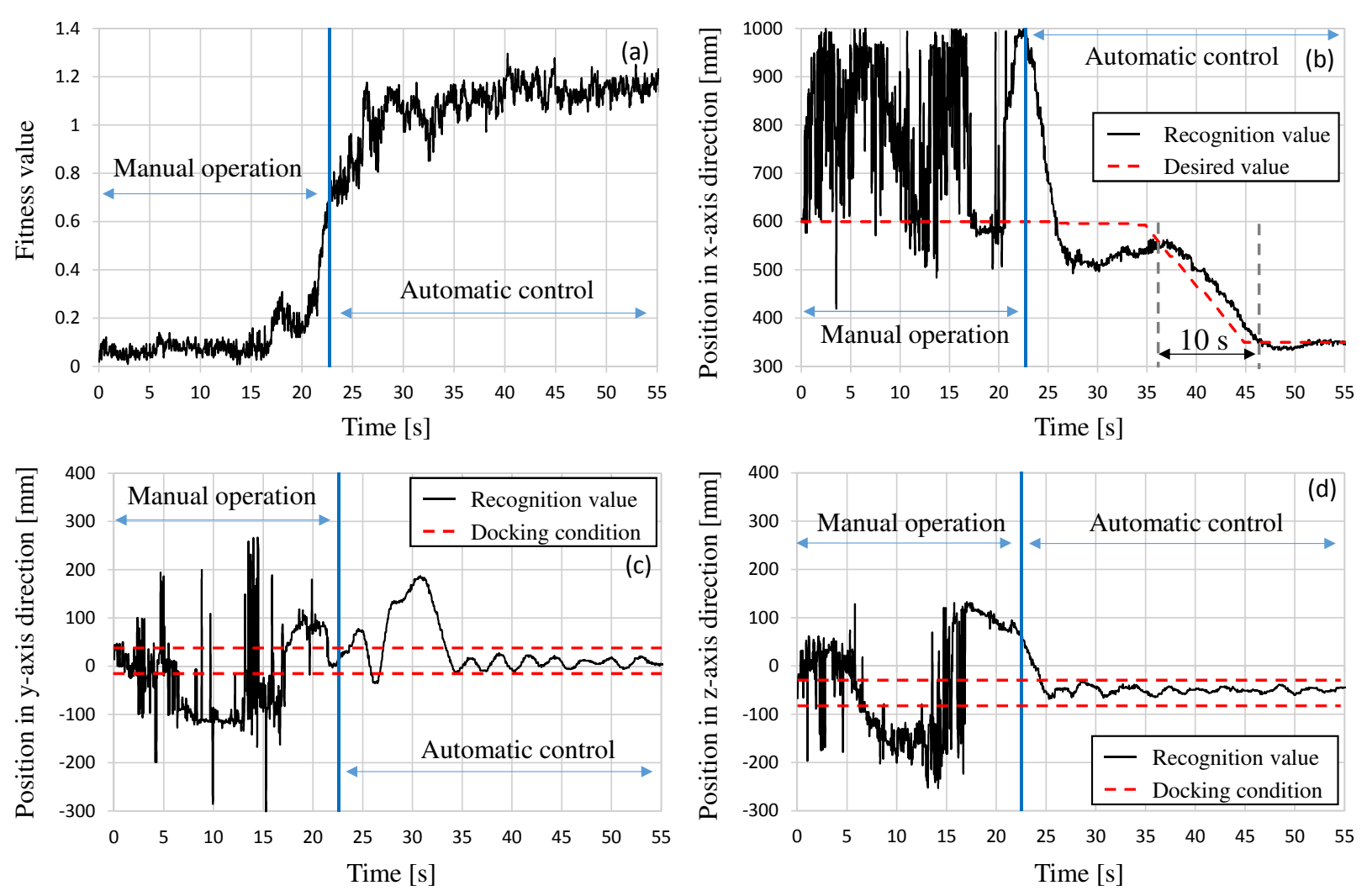

Fig. 13 Docking result 3 : (a)fitness value, (b)(c)(d)recognized positions in $\mathrm{x}, \mathrm{y}$ and $\mathrm{z}$ axes direction. 

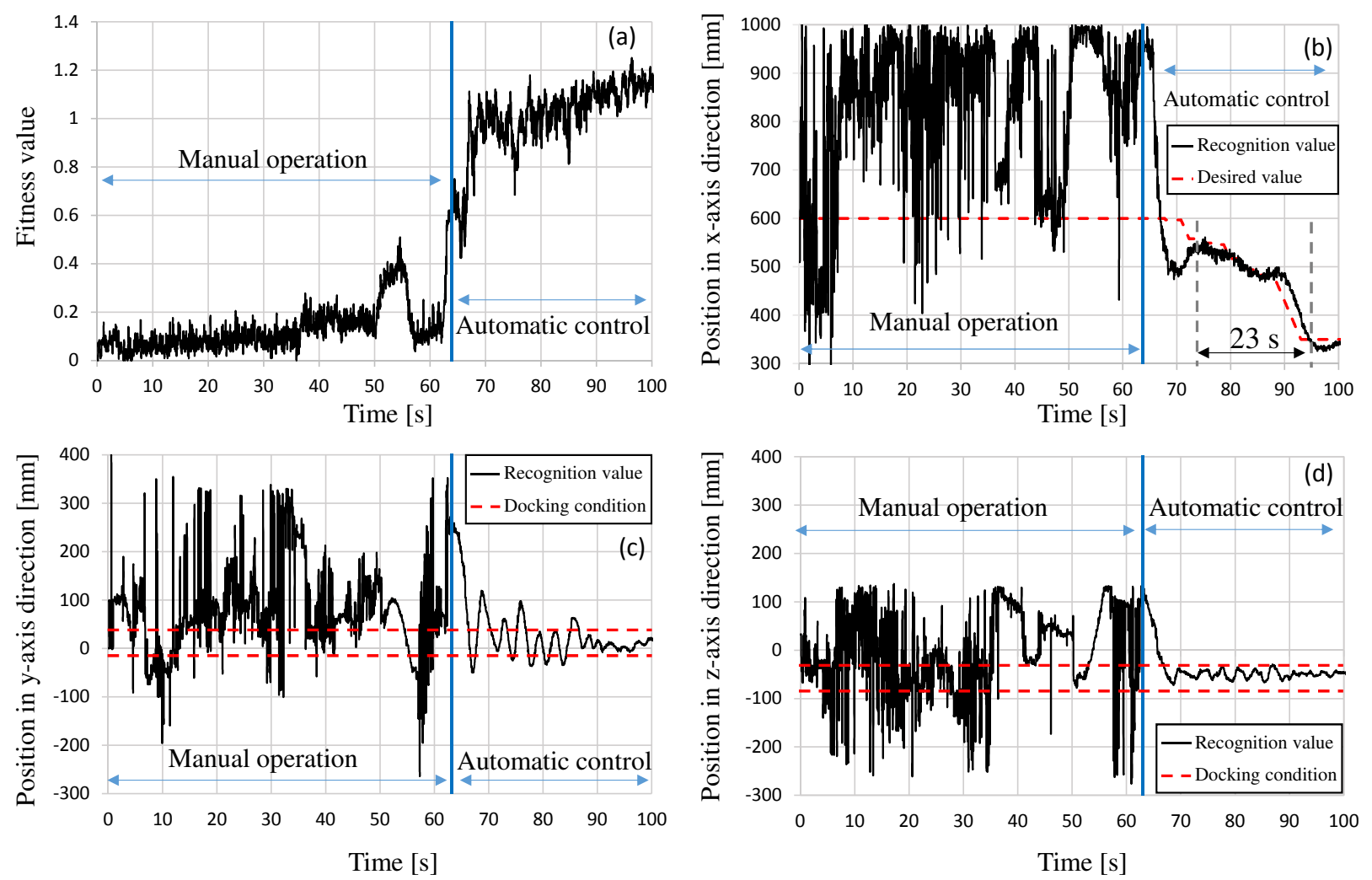

Fig. 14 Docking result 4 : (a)fitness value, (b)(c)(d)recognized positions in $\mathrm{x}, \mathrm{y}$ and $\mathrm{z}$ axis direction.

\section{4. 結言}

海底での水中ロボットの長時間活動を目的として仮想給電装置との嵌合に関する研究を進めている. 本報では, Real-time Multi-step GA（RM-GA）を用いた複眼カメラによる 3D マーカーとの相対的位置・姿勢の実時間 3 次元 認識に基づいて Visual Servoing を行い，実海域での ROVの嵌合実験について報告した。実験の結果，(1) 実海域 環境下で RM-GA により Visual Servoing が可能であること示した。(2) 直径 $70 \mathrm{~mm}$ の嵌合穴に $8 \times 6 \mathrm{~mm}$ の嵌合棒 を全 5 回の試行で，4回嵌合させることに成功した。(3) 複眼による 3D-MoS 制御法は, ROV が 3D マーカーに接 近するにつれ制御性能が安定することが分かった。 なお失敗した嵌合実験では, 海水の動摇によりビジュアルサー ボ中に ROV の方位が鉛直軸反時計方向に大きく変化し, マーカーが左カメラ画像に写らない状況になったことに より自動制御による自動嵌合手続きが自動的に中断された. 現時点で見失ったマーカーを能動的に探しビジュアル サーボ状態に復帰する機能を備えていないためである.

謝 辞

本研究では広和株式会社マリンシステム部の協力を得ました。ここに謝意を表します.

文献

石井和男, 園田隆, 中西亮汰, 河島晋, 日高翔太, 自立型水中ロボットのドッキング制御に関する研究, ロボティクス・ メカトロニクス講演会 2015 (2015), 2A2-D06.

Lwin, K.N., Yonemori, K., Myint, M., Mukada, N., Minami, M., Yanou, A. and Matsuno, T., Performance analyses and optimization of real-time multi-step GA for visual-servoing based underwater vehicle, IEEE/OES/MTS Int. Conference Techno-Ocean 2016 (2016), pp.519-526

松山隆司, 久野義徳, 井宮淳, コンピュータビジョン：技術評論と将来展望 (1998), 新技術コミュニケーションズ. 見浪護, 西村健太, 須浪唯介, 矢納陽, 崔禹, 山下学, 石山新太郎, 3 次元複眼立体認識を用いた除染ロボットの提案と 精度検証実験, 日本機械学会論文集, Vol.81, No.831 (2015), DOI: 10.1299/transjsme.15-00216. 
Myo, M., Yonemori, K., Yanou, A., Minami, M. and Ishiyama, S., Visual-servo-based autonomous docking system for underwater vehicle using dual-eyes camera 3D-pose tracking, IEEE/SICE International Symposium on System Integration(2015), pp.989-994.

中原智治, 顧海松, 荒木秀和, 藤井裕之, 廣田雅之, 3 次元認識によるビンピッキングシステムの実用化, システム制 御情報学会論文誌, Vol.14, No.4 (2001), pp.226-232.

Nishimura, K., Hou, S., Maeda, K., Minami,M. and Yanou, A., Analyses on on-line evolutionary optimization performance for pose tracking while eye-vergence visual servoing, Proceedings of 2013 IEEE International Conference on Mechatronics and Automation (ICMA)(2013), pp.698-703.

小野桂太郎, 小川卓哉, 前田雄介, 中谷茂樹, 永安剛, 清水領, 大内規嵩, ステレオビジョンを用いた巻ばねの認識とビ ンピッキング, 日本機械学会論文集 C 編, Vol.79, No.804 (2013), pp.2769-2779.

Palomeras, N., Penalver, A., Massot-Campos, M., Vallicrosa, G., Negre, P.L., Fernandez, J.J., Ridao, P., Sanz, P.J., OliverCodina, G. and Palomer, A., I-AUV docking and intervention in a subsea panel, Proceedings of 2014 IEEE/RSJ International Conference on Intelligent Robots and Systems(2014b), pp.2279-2285.

Palomeras, N., Ridao, P., Ribas, D. and Vallicrosa, G., Autonomous I-AUV docking for fixed-based manipulation, Preprints of the International Federation of Automatic Control(2014a), pp.12160-12165.

Park, J-Y., Jun, B-H., Lee, P-M. and Oh, J., Experiments on vision guided docking of an autonomous underwater vehicle using one camera, Ocean Engineering, Vol.36, No.1(2009), pp.48-61.

宋薇, 見浪護, フィードフォワード遺伝的認識法を用いた 3-D ビジュアルサーボ, 日本ロボット学会誌, Vol.28, No.5 (2010), pp.591-598.

宋薇, 見浪護, 青柳誠司, クォータニオンを用いたフィードフォワードオンラインポーズ遺伝的認識法, 日本ロボッ 卜学会誌, Vol.28, No.1 (2010), pp.55-64.

Song, W., Yu, F. and Minami, M., 3D visual servoing by feedforward evolutionary recognition, Journal of Advanced Mechanical Design, Systems, and Manufacturing, Vol.4, No.4(2010), pp.739-755.

Suzuki, H. and Minami, M., Visual servoing to catch fish using global/local GA search, IEEE/ASME Transactions on Mechatronics, Vol.10, No.3(2005), pp.352-357.

Ura, T., Kurimoto, Y., Kondo, H., Nose, Y., Sakamaki, T. and Kuroda, Y., Observation behavior of an AUV for ship wreck investigation, Proceedings of the OCEANS 2005 MTS/IEEE, Vol.3(2005), pp.2686-2691.

徐剛, 辻三郎, 3 次元ビジョン (2005), 共立出版.

矢納陽, 大西翔太, 石山新太郎, 見浪護, 水中自動充電を目指したビジュアルサーボ型水中ロボットの自動嵌合制御, 日本機械学会論文集, Vol.81, No.832(2015), DOI: 10.1299/transjsme.15-00391.

矢納陽, 大西祥太, 米森健太, 石山新太郎, 藤本勝樹, 見浪護, ビジュアルサーボによる水中ロボットの位置・姿勢制 御, 第 6 回コンピューテーショナル・インテリジェンス研究会 (2014).

矢納陽, 米森健太, 石山新太郎, 見浪護, 松野隆幸, 3 次元マーカーを用いたビジュアルサーボ型水中ロボットの気泡 外乱に対する制御特性, 計測自動制御学会論文集, Vol.52, No.5(2016), pp.284-291.

Yu, F., Minami, M., Song, W. and Yanou, A., Eye-vergence visual servoing enhancing Lyapunov-stable trackability, Artificial Life and Robotics, Vol.18, No.1-2(2013), pp.27-35.

\section{References}

Ishii, K., Sonoda, T., Nakanishi, R., Kawashima, S. and Hidaka, S., Research on docking control of autonomous underwater vehicle, ROBOMECH2015 in Kyoto(2015), 2A2-D06 (in Japanese).

Lwin, K.N., Yonemori, K., Myint, M., Mukada, N., Minami, M., Yanou, A. and Matsuno, T., Performance analyses and optimization of real-time multi-step GA for visual-servoing based underwater vehicle, IEEE/OES/MTS Int. Conference Techno-Ocean 2016 (2016), pp.519-526

Matsuyama, T., Kuno, Y. and Imiya, A., Computer vision:technical review and future view (1998), New Technology Communications (in Japanese).

Minami, M., Nishimura, K., Sunami, Y., Yanou, A., Cui, Y., Yamashita, M. and Ishiyama, S., A proposal of decontamination robot using 3D hand-eye-dual-cameras solid recognition and accuracy validation, Transactions of 
the JSME (in Japanese), Vol.81, No.831 (2015), DOI: 10.1299/transjsme.15-00391.

Myo, M., Yonemori, K., Yanou, A., Minami, M. and Ishiyama, S., Visual-servo-based autonomous docking system for underwater vehicle using dual-eyes camera 3D-pose tracking, IEEE/SICE International Symposium on System Integration(2015), pp.989-994.

Nakahara, T., Gu, H., Araki, H., Fujii, H. and Hirota, M., A practical bin-picking system using 3D object recognition, Transactions of the Institute of Systems, Control and Information Engineers, Vol.14, No.4 (2001), pp.226-232 (in Japanese).

Nishimura, K., Hou, S., Maeda, K., Minami, M. and Yanou, A., Analyses on on-line evolutionary optimization performance for pose tracking while eye-vergence visual servoing, Proceedings of 2013 IEEE International Conference on Mechatronics and Automation (ICMA)(2013), pp.698-703.

Ono, K., Ogawa, T., Maeda, Y., Nakatani, S., Nagayasu, G., Shimizu, R. and Ouchi, N., Recognition and bin-picking of coil springs by stereo vision, Transactions of the Japan Society of Mechanical Engineers, Series C, Vol.79, No.804 (2013), pp.2769-2779 (in Japanese).

Palomeras, N., Penalver, A., Massot-Campos, M., Vallicrosa, G., Negre, P.L., Fernandez, J.J., Ridao, P., Sanz, P.J., OliverCodina, G. and Palomer, A., I-AUV docking and intervention in a subsea panel, Proceedings of 2014 IEEE/RSJ International Conference on Intelligent Robots and Systems(2014b), pp.2279-2285.

Palomeras, N., Ridao, P., Ribas, D. and Vallicrosa, G., Autonomous I-AUV docking for fixed-based manipulation, Preprints of the International Federation of Automatic Control(2014a), pp.12160-12165.

Park, J-Y., Jun, B-H., Lee, P-M. and Oh, J., Experiments on vision guided docking of an autonomous underwater vehicle using one camera, Ocean Engineering, Vol.36, No.1(2009), pp.48-61.

Song, W. and Minami, M., 3-D visual servoing using feedforward evolutionary recognition, Journal of the Robot Society of Japan, Vol.28, No.5 (2010), pp.591-598 (in Japanese).

Song, W., Minami, M. and Aoyagi, S., Feedforward on-line pose evolutionary recognition based on quaternion, Journal of the Robot Society of Japan, Vol.28, No.1 (2010), pp.55-64 (in Japanese).

Song, W., Yu, F. and Minami, M., 3D visual servoing by feedforward evolutionary recognition, Journal of Advanced Mechanical Design, Systems, and Manufacturing, Vol.4, No.4(2010), pp.739-755.

Suzuki, H. and Minami, M., Visual servoing to catch fish using global/local GA search, IEEE/ASME Transactions on Mechatronics, Vol.10, No.3(2005), pp.352-357.

Ura, T., Kurimoto, Y., Kondo, H., Nose, Y., Sakamaki, T. and Kuroda, Y., Observation behavior of an AUV for ship wreck investigation, Proceedings of the OCEANS 2005 MTS/IEEE, Vol.3(2005), pp.2686-2691.

Xu, G. and Tsuji, S., Three-dimensional vision (2005), Kyoritsu Shuppan (in Japanese).

Yanou, A., Ohnishi, S., Ishiyama, S. and Minami, M., Autonomous docking control of visual-servo type underwater vehicle system aiming at underwater automatic charging, Transactions of the JSME (in Japanese), Vol.81, No.832(2015), DOI: 10.1299/transjsme.15-00391.

Yanou, A., Ohnishi, S., Yonemori, K., Ishiyama, S., Fujimoto, K. and Minami, M., Position and orientation control of underwater vehicle system by visual servoing, Sixth SICE Symposium on Computational Intelligence (2014) (in Japanese).

Yanou, A., Yonemori, K., Ishiyama, S., Minami, M. and Matsuno, T., Control characteristics of visual-servo type underwater vehicle system using three-dimensional marker for air bubble disturbance, Transactions of the Society of Instrument and Control Engineers, Vol.52, No.5(2016), pp.284-291 (in Japanese).

Yu, F., Minami, M., Song, W. and Yanou, A., Eye-vergence visual servoing enhancing Lyapunov-stable trackability, Artificial Life and Robotics, Vol.18, No.1-2(2013), pp.27-35. 